\title{
PENGARUH PROFITABILITAS, LIKUIDITAS, SOLVABILITAS DAN UKURAN PERUSAHAAN TERHADAP KETEPATAN WAKTU PENYAMPAIAN LAPORAN KEUANGAN PADA PERUSAHAAN MANUFAKTUR DI BEI
}

\author{
Jessica Carolina $^{1 *}$, Vargo Christian L. Tobing ${ }^{2}$. \\ ${ }^{1}$ Mahasiswa Program Studi Akuntansi, Universitas Putera Batam \\ ${ }^{2}$ Dosen Program Studi Akuntansi, Universitas Putera Batam
}

email: jssicahkc@gmail.com

\begin{abstract}
The timeliness of submitting financial statements is a rule that must be applied by all companies. Based on the Decree of the Chairperson of the Capital Market and Financial Institution Supervisors with number: KEP-431/BL/2012 stating that public companies that have effective registration must submit annual reports to BAPEPAM and LK no later than four months after the end of the financial year. This study aims to examine the effect of profitability, liquidity, solvency and firm size on the timeliness of financial statement submission. The population in this study is a consumer goods manufacturing sector manufacturing company listed on the Indonesia Stock Exchange. The sample was selected as many as 21 companies using the purposive sampling method. The analytical method is logistic regression. The data used is secondary data obtained through the web.idx.id website in the form of annual financial statements for the periode 2013-2017. The results of the study were tested using the SPSS version 24 application which showed that partial profitability (ROA), liquidity $(C R)$, solvency (DAR) dan company size (SIZE) or simultaneously did not significantly influence the timeliness of financial statement submission.
\end{abstract}

Keywords: Profitability; Liquidity; Solvability; Company Size; Timeliness of Submission of Financial Statements

\section{PENDAHULUAN}

Pasar modal yang perkembangannya semakin cepat didalam dunia bisnis, membutuhkan informasi yang digunakan sebagai dasar untuk mengambil keputusan. Informasi yang penting didalam dunia bisnis salah satunya adalah laporan keuangan (Nurmiati, 2016). Ketepatan waktu merupakan suatu hal penting yang perlu diperhatikan perusahaan go public dalam melakukan pelaporan keuangan, sebab keterlambatan penyampaian informasi finansial dapat menyebabkan keputusan yang didapatkan kurang berkualitas. Tepatnya waktu untuk penyampaian informasi keuangan tercantum dalam UU no. 8 tahun 1995 mengenai pasar modal, yang menerangkan bahwa perusahaan go public harus melaporkan laporan keuangannya untuk Badan Pengawasan Pasar Modal juga Laporan Keuangan, setelah itu mengumumkan ke masyarakat (Imaniar, 2016). Keputusan Ketua Badan Pengawas Pasar Modal Dan Lembaga Keuangan, Tanggal 1 Agustus 2012 dengan nomor: KEP-431/BL/2012 menyebutkan bahwa perusahaan go public yang telah efektif mendaftar diwajibkan melakukan pelaporan keuangan tahunan untuk BAPEPAM dan LK dengan batas paling lambat 120 hari sesudah akhir tahun buku.

Profitabilitas merupakan suatu berita penting yang bisa dipakai bagi investor dalam estimasi dalam rangka melakukan penanaman modal, dan adalah suatu penunjuk kesuksesan operasi suatu kegiatan usaha sebab profitabilitas merepresentasikan derajat efektivitas yang telah diperoleh perusahaan (Nurmiati, 2016). Profitabilitas suatu kegiatan usaha yang tinggi penyampaian laporan keuangannya cenderung tepat waktu karena untuk menunjukkan kepada publik bahwa perusahaan mempunyai kemampuan dalam menghasilkan laba yang cukup tinggi. 
Likuiditas ialah kecakapan suatu kegiatan usaha dalam memenuhi utang berjangka pendek pada waktu yang ditetapkan (Choiruddin, 2015). Likuiditas suatu perusahaan yang meningkat, penyampaian laporan keuangannya cenderung tepat pada waktu sebab adalah perusahaan yang cukup mampu dalam memenuhi kewajiban jangka pendek. Investor mempunyai kepentingan terhadap rasio likuiditas dalam mendapatkan pengembalian jumlah pokok pinjaman beserta bunganya. Solvabilitas ialah alat dalam menghitung besarnya kegiatan usaha yang tergantung pada kreditur untuk membiayai aktivitas perusahaan (Lathiefatunnisa Nur Islam, 2015). Solvabilitas menilai kapabilitas suatu perusahaan dalam melakukan pembayaran kewajiban yang jatuh tempo, suatu perusahaan yang tinggi cenderung terlambat menyampaikan laporan keuangan karena perusahaan bergantung kepada kreditur dalam membiayai aktivitas perusahaan maka akan mengakibatkan perusahaan mengalami kesulitan keuangan. Ukuran perusahaan ialah skala untuk menggambarkan besar atau kecil suatu perusahaan yang bisa digunakan bermacam cara, seperti: jumlah aktiva, log natural size, harga pasar saham, dan sebagainya. Ukuran suatu kegiatan usaha yang besar penyampaian laporan keuangannya cenderung tepat pada waktunya sebab semakin baik sistem pengendalian internal sehingga menurunkan tingkat kesalahan dalam menyusun laporan keuangan.

\section{TINJAUAN PUSTAKA Profitabilitas}

Menurut Hanafi \& Halim (2016: 81) rasio profitabilitas ialah suatu rasio yang digunakan untuk menilai efektivitas suatu kegiatan usaha dalam mendapatkan laba pada tingkat aset, penjualan, maupun ekuitas saham. Rasio ini dimana mempunyai tujuan menghitung nilai potensi manajemen menjalankan operasional didalam perusahaan. Penelitian yang diteliti, profitabilitas dihitung memakai rasio Return on Assets (ROA). ROA menerangkan keterampilan kegiatan usaha untuk memperoleh laba setelah pajak yang memanfaatkan semua aktiva yang dimilikinya. Rumus Return on Assets (ROA) adalah (Sudana, 2011: 22):

ROA = Earning After Taxes/Total Asset

\section{Likuiditas}

Menurut Fahmi (2015: 121) rasio likuiditas merupakan kemahiran sebuah perusahaan untuk melunasi utang jangka pendek tepat pada waktu. Contoh: pembayaran listrik, air, telepon, upah karyawan, teknisi maupun lembur dan lain-lain. Maka dari itu rasio likuiditas biasanya juga dinamakan sebagai short term liquidity. Untuk penelitian yang diteliti, likuiditas dihitung dengan memanfaatkan Current Ratio (CR) yang mencerminkan kapabilitas perusahaan membayar utang berjangka pendek memakai aset lancar, atau banyaknya aset lancar ada untuk penutupan setiap rupiah utang jangka pendek Rumus Current Asset Ratio (CR) adalah (Samryn, 2012: 417):

$\mathrm{CR}=$ Aktiva Lancar/Kewajiban Jangka Pendek

\section{Solvabilitas}

Menurut Hery (2016: 70) rasio solvabilitas disebut juga leverage adalah rasio yang dimanfaatkan dalam menilai sampai dimana aktiva suatu perusahaan dibiayai oleh kewajiban. Rasio solvabilitas disebut juga leverage dipakai dalam menghitung besarnya utang yang harus dibebankan oleh perusahaan pada kegiatan untuk memenuhi aset. Penelitian yang diteliti, solvabilitas dihitung dengan memakai rasio Debt to Asset Ratio (DAR). Pengukuran ini berguna menghitung dana yang disediakan kreditur seberapa jauhrumus Debt to Asset Ratio (DAR) adalah (Hanafi \& Halim, 2016: 79):

DAR $=$ Total Utang/Total Aset

\section{Ukuran Perusahaan}

Menurut Hery (2017: 11) ukuran merupakan sebuah perbandingan besar atau kecil terhadap suatu objek. Apabila definisi untuk ini digabungkan bersama perusahaan ataupun sebuah lembaga, berarti ukuran suatu perusahaan didefinisikan sebagai sebuah perbandingan besar maupun kecil usaha dari sebuah perusahaan ataupun organisasi. Dalam penelitian yang 
diteliti oleh peneliti, ukuran perusahaan dihitung dengan memanfaatkan log natural dari jumlah aset. Rumus yang dipakai untuk menghitung log natural, yaitu (Nurmiati, 2016):

SIZE $=\operatorname{Ln}($ Total Aset $)$

\section{Ketepatan Waktu Penyampaian Laporan Keuangan}

Hery (2016: 2) mendefinisikan laporan keuangan (financial statement) ialah serangkaian kegiatan proses mencatat dan mengikhtisar data transaksi yang merupakan produk akhir. Seorang akuntan diperlukan mahir untuk melakukan organisasi semua data akuntansi sampai menghasilkan laporan keuangan. Ketepatan waktu merupakan informasi yang harus disediakan saat dibutuhkan, terutama didalam setiap pengambilan keputusan bisnis (Hery, 2016: 167). Variabel ini menggunakan skala nominal, dinilai dengan memakai variabel dummy. Kategori bagi perusahaan melakukan pelaporan keuangan tepat waktu yaitu kode 1, perusahaan melakukan pelaporan keuangan tidak tepat waktu yaitu kode 0 .

Hipotesis dalam penelitian ini adalah:

$\mathrm{H}_{1}$ : Profitabilitas berpengaruh signifikan terhadap ketepatan waktu penyampaian laporan keuangan pada perusahaan manufaktur yang terdaftar di BEI.

$\mathrm{H}_{2}$ : Likuiditas berpengaruh signifikan terhadap ketepatan waktu penyampaian laporan keuangan pada perusahaan manufaktur yang terdaftar di BEI.

$\mathrm{H}_{3}$ : Solvabilitas berpengaruh signifikan terhadap ketepatan waktu penyampaian laporan keuangan pada perusahaan manufaktur yang terdaftar di BEI.

$\mathrm{H}_{4}$ : Ukuran Perusahaan berpengaruh signifikan terhadap ketepatan waktu penyampaian laporan keuangan pada perusahaan manufaktur yang terdaftar di BEI.

$\mathrm{H}_{5}$ : Profitabilitas, likuiditas, solvabilitas dan ukuran perusahaan secara simultan berpengaruh signifikan terhadap ketepatan waktu penyampaian laporan keuangan pada perusahaan manufaktur yang terdaftar di BEI.

\section{METODE}

Penelitian yang diteliti bertujuan dalam menguji pengaruh antara profitabilitas, likuiditas, solvabilitas dan ukuran perusahaan terhadap ketepatan waktu penyampaian laporan keuangan. Variabel independen yang dipakai adalah profitabilitas, likuiditas, solvabilitas dan ukuran perusahaan. Variabel dependen yang dipakai adalah ketepatan waktu penyampaian laporan keuangan. Populasi yang digunakan untuk meneliti adalah seluruh entitas manufaktur yang berjalan pada sektor industri barang konsumsi dimana telah terdaftar di Bursa Efek Indonesia yang mempublikasikan laporan keuangan tahunan yang sudah audit dan diumumkan di Bursa Efek Indonesia untuk kurun waktu 2013-2017 sebanyak 41 Perusahaan. Sampel dipilih sejumlah 21 perusahaan menggunakan metode purposive sampling.

Teknik pengumpulan data menggunakan dokumentasi, adalah sebuah cara mengunduh informasi keuangan tahunan entitas manufaktur bidang industri barang konsumsi tahun 20132017 di Bursa Efek Indonesia dari sebuah situs bernama web.idx.id yang resmi, dilakukan pula kajian pustaka dari jurnal, peraturan, maupun hasil riset berbagai sumber, baik dari buku maupun dari perpustakaan. Menganalisis data dengan memanfaatkan aplikasi SPSS (Statistical Package for the Social Science) untuk versi 24. Metode untuk menganalisis adalah regresi logistik. Uji perlu dilakukan adalah statistik deskriptif serta uji hipotesis yang terdiri dari uji keseluruhan model, koefisien determinasi, kelayakan model regresi, multikolonieritas, ketepatan prediksi, koefisien regresi dan omnibus tests of model coefficients. Penelitian berlangsung pada Bursa Efek Indonesia yang mempunyai alamat di Komplek Mahkota Raya Blok A No. 11 Batam Center, Kota Batam, Kepulauan Riau, Indonesia. 


\section{HASIL DAN PEMBAHASAN \\ Statistik Deskriptif}

Analisis uji ini bertujuan dalam melakukan pengujian serta penjelasan ciri-ciri sampel yang akan diobservasi oleh peneliti. Hasil pengujian statistik deskriptif dapat dilihat dari tabel 1 dibawah ini:

Tabel 1. Hasil Uji Statistik Deskriptif

\begin{tabular}{llrrrr}
\hline & $\mathrm{N}$ & \multicolumn{1}{c}{ Min } & Max & \multicolumn{1}{c}{ Mean } & \multicolumn{1}{c}{ Std. Deviation } \\
\hline ROA & 105 & 1,59 & 65,72 & 15,1482 & 11,65722 \\
CR & 105 &, 51 & 10,25 & 2,9732 & 2,01407 \\
DAR & 105 &, 07 & 2,75 &, 4058 &, 28784 \\
SIZE & 105 & 26,81 & 32,15 & 29,1123 & 1,48023 \\
Timeliness & 105 & 0 & 1 &, 49 &, 502 \\
Valid N (listwise) & 105 & & & &
\end{tabular}

Sumber: Data sekunder yang diolah dalam SPSS v.24 (2018)

Berdasarkan tabel 1 diatas, nilai $\mathrm{N}$ dengan jumlah data 105. Pada variabel profitabilitas yang diukur dengan Return on Assets memiliki nilai minimum sebesar 1,59 dan nilai maksimum sebesar 65,72. Nilai rata-rata (mean) sebesar 15,1482 dan nilai standar deviasi sebesar 11,65722. Variabel likuiditas yang diukur dengan Current Ratio memiliki nilai minimum sebesar 0,51 dan maksimum sebesar 10,25. Nilai rata-rata sebesar 2,9732 dan nilai standar deviasi sebesar 2,01407. Variabel solvabilitas yang diukur dengan Debt to Asset Ratio memiliki nilai minimum dan maksimum berturut-turut sebesar 0,07 dan 2,75. Nilai rata-rata sebesar 0,4058 serta standar deviasi sebesar 0,28784. Sedangkan variabel ukuran perusahaan yang diukur dengan log natural total aset memiliki nilai minimum sebesar 26,81 dan nilai maksimum sebesar 32,15. Nilai rata-rata sebesar 29,1123 dan standar deviasi sebesar 1,48023.

Tabel 2. Hasil Uji Statistik Deskriptif Pada Variabel Dummy

\begin{tabular}{llcc}
\hline \multicolumn{1}{c}{ Variabel } & \multicolumn{1}{c}{ Kategori } & Frekuensi & Persen \\
\hline Ketepatan Waktu Penyampaian & 0 : Tidak tepat waktu & 54 & 51,4 \\
Laporan Keuangan & 1 : Tepat waktu & 51 & 48,6
\end{tabular}

Sumber: Data sekunder yang diolah dalam SPSS v.24 (2018)

Pada tabel 2 diatas menunjukkan bahwa entitas yang melakukan pelaporan keuangan tahunan tidak tepat pada waktunya berjumlah 54 data perusahaan atau sebesar $51,4 \%$ dari jumlah pengujian untuk 105 data perusahaan, kemudian entitas yang melakukan pelaporan keuangan tahunan tepat pada waktunya berjumlah 51 data perusahaan atau sebesar 48,6\% dari jumlah pengujian untuk 105 data perusahaan, sehingga dapat diartikan bahwa perusahaan yang menyampaikan laporan keuangan tahunan tidak tepat waktu lebih banyak daripada perusahaan yang menyampaikan laporan keuangan secara tepat waktu.

\section{Uji Hipotesis}

\section{Uji Keseluruhan Model}

Untuk memastikan kecocokan keseluruhan model (Overall Model Fit), yaitu apabila adanya penurunan hasil -2Loglikelihood diawal (Block Number: 0) dengan -2Loglikelihood diakhir (Block Number: 1) merupakan sebuah model regresi yang baik (Santoso, 2012: 209). Pada tabel 3 dapat dilihat hasil uji keseluruhan model:

Tabel 3. Hasil Uji Keseluruhan Model Awal

$$
\text { Iteration History }{ }^{\mathbf{a}, \mathbf{b}, \mathbf{c}}
$$

\begin{tabular}{llrr}
\hline \multirow{2}{*}{ Iteration } & \multirow{2}{*}{-2 Log likelihood } & \multicolumn{2}{c}{ Coefficients } \\
\cline { 4 - 4 } Step 0 & 1 & & Constant \\
& 2 & 145,475 &,- 057 \\
& 2 & 145,475 &,- 057 \\
\hline
\end{tabular}

Sumber: Data sekunder yang diolah dalam SPSS 24 (2018) 
Tabel 4. Hasil Uji Keseluruhan Model Akhir Iteration History ${ }^{\mathrm{a}, \mathrm{b}, \mathrm{c}, \mathrm{d}}$

\begin{tabular}{|c|c|c|c|c|c|c|c|}
\hline \multirow{2}{*}{\multicolumn{2}{|c|}{ Iteration }} & \multirow{2}{*}{$\begin{array}{c}-2 \text { Log } \\
\text { likelihood }\end{array}$} & \multicolumn{5}{|c|}{ Coefficients } \\
\hline & & & Constant & ROA & CR & DAR & SIZE \\
\hline \multirow[t]{5}{*}{ Step 1} & 1 & 143,119 &,- 592 & ,013 &,- 101 &,- 784 & ,033 \\
\hline & 2 & 142,902 &,- 302 & 015 &,- 136 & $-1,256$ & ,032 \\
\hline & 3 & 142,877 &,- 165 & ,015 &,- 152 & $-1,483$ & ,031 \\
\hline & 4 & 142,877 &,- 148 & ,015 &,- 154 & $-1,512$ & 031 \\
\hline & 5 & 142,877 &,- 148 & ,015 &,- 154 & $-1,513$ & ,031 \\
\hline
\end{tabular}

Sumber: Data sekunder yang diolah dalam SPSS 24 (2018)

Tabel 3 dan 4 diatas merupakan hasil uji keseluruhan model dan akhir. Berdasarkan tabel 3 menunjukkan bahwa nilai -2Loglikelihood awal sebesar 145,475. Tabel 4 nilai 2 Loglikelihood akhir sebesar 142,877. Kedua tabel 3 dan 4 diatas, timbul penurunan nilai antara -2Loglikelihood awal dan -2Loglikelihood akhir sejumlah 2,598. Hal ini berarti keseluruhan model baik dan fit.

\section{Uji Koefisien Determinasi}

Uji koefisien Determinasi dalam analisis regression logistic dibuktikan dengan menggunakan nilai Nagelkerke's $R$ Square yang pada intinya dalam menilai jauhnya kecakapan sebuah model dalam menerangkan berbagai variabel bebas (Ghozali, 2016: 95). Koefisien dterminasi ditunjukkan dalam tabel 5 berikut:

Tabel 5. Hasil Uji Koefisien Determinasi

\begin{tabular}{cc}
\multicolumn{2}{c}{ Model Summary } \\
\hline Step & Nagelkerke R Square \\
\hline 1 &, 033 \\
\hline
\end{tabular}

Sumber: Data sekunder yang diolah dalam SPSS 24 (2018)

Pada tabel ke 5 tertera diatas, hasil Nagelkerke's $R$ Square dimana merupakan modifikasi dari koefisien Cox dan Snell, caranya membagikan Cox dan Snell's $\mathrm{R}^{2}$ bersama nilai maksimum. Hasil Nagelkerke's $R$ Square di tabel menunjukkan hasilnya 0,033. Hal ini diartikan bahwa variasi variabel dependen yang dapat digambarkan melalui varias variabel independen berjumlah 3,3\%. Untuk 96,7 \% lebihnya dijelaskan oleh variabel selain variabel dalam penelitian ini. variabel didalam penelitian ini yaitu profitabilitas, likuiditas, solvabilitas dan ukuran perusahaan.

\section{Uji Kelayakan Model Regresi}

Pengujian kelayakan model regresi diukur dengan memanfaatkan Hosmer and Lemeshow's Goodness of Fit Test. Apabila nilai lebih rendah dari atau sama dengan 0,05, sehingga menolak hipotesis 0 , kemudian apabila nilai lebih tinggi daripada 0,05 , maka hipotesis nol tidak ditolak yang berarti model dapat diterima karena data observasinya cocok (Ghozali, 2016: 329). Tabel 6 dibawah merupakan hasil pengujian kelayakan model regresi:

Tabel 6. Hasil Uji Kelayakan Model Regresi

Hosmer and Lemeshow Test

\begin{tabular}{cccc}
\multicolumn{4}{c}{ Hosmer and Lemeshow Test } \\
\hline Step & Chi-square & $d f$ & Sig. \\
\hline 1 & 7,385 & 8 &, 496 \\
\hline
\end{tabular}

Sumber: Data sekunder yang diolah dalam SPSS 24 (2018)

Berdasarkan tabel 6 tertera diatas, nilai statistik Hosmer and Lemeshow's Goodness of Fit memiliki tingkat signifikansi hasilnya 0,496 . Hal ini menunjukkan nilai yang ditunjukkan ini lebih tinggi daripada 0.05. Sehingga tidak dapat menolak hipotesis nol. oleh sebab itu, model ini dapat digunakan atau digunakan. Model ini mampu memprediksi nilai yang diobservasi. Penerimaan model ini karena cocok dengan data penelitian yang telah digunakan oleh peneliti dalam melakukan diobservasi. 


\section{Uji Multikolonieritas}

Uji ini dilakukan karena bertujuan dalam melakukan pengujian bahwa benarkah model regresi mempunyai hubungan diantara variabel independen. Suatu bentuk regresi disebut bagus sebenarnya tidak ada hubungan antar variabel bebas. Perlakuan uji multikolonieritas dapat diterangkan dari matrik korelasi dimana apabila antar variabel independen terdapat korelasi lebih tinggi dari 0,90 maka merupakan indikasi adanya multikolonieritas (Ghozali, 2016: 103). Tabel 7 dapat melihat hasil uji multikolonieritas:

Tabel 7. Hasil Uji Multikolonieritas

\begin{tabular}{llrrrrr}
\multicolumn{7}{c}{ Correlation Matrix } \\
\hline Step 1 & Constant & 1,000 &, 046 &,- 337 &,- 259 &,- 968 \\
& ROA &, 046 & 1,000 &,- 161 &,- 207 &,- 063 \\
& CR &,- 337 &,- 161 & 1,000 &, 757 &, 124 \\
& DAR &,- 259 &,- 207 &, 757 & 1,000 &, 033 \\
& SIZE &,- 968 &,- 063 &, 124 &, 033 & 1,000 \\
\hline
\end{tabular}

Sumber: Data sekunder yang diolah dalam SPSS 24 (2018)

Berdasarkan tabel 7 diatas, Korelasi antara variabel profitabilitas (ROA) dan variabel likuiditas (CR) adalah -0,161. Korelasi antara variabel profitabilitas (ROA) dan variabel solvabilitas (DAR) adalah -0,207. Korelasi antara variabel profitabilitas (ROA) dan variabel ukuran perusahaan (SIZE) adalah -0,063. Korelasi antara variabel likuiditas (CR) dan variabel solvabilitas (DAR) adalah 0,757. Korelasi antara variabel likuiditas dan variabel ukuran perusahaan (SIZE) adalah 0,124. Korelasi antara variabel solvabilitas (DAR) dan variabel ukuran perusahaan (SIZE) adalah 0,033. Hasil dari tabel diatas menunjukkan bahwa hasil koefisien korelasi seluruh variabel bebas berada dibawah 0,90 , yang bisa diartikan bahwa tidak adanya gejala multikolonieritas antara variabel-variabel independen.

\section{Uji Ketepatan Prediksi}

Uji ketepatan prediksi dengan melihat hasil classification table $2 \times 2$ yang menggambarkan hasil prediksi yang benar dan tidak benar (Ghozali, 2016: 329). Tabel 8 dapat melihat hasil uji ketepatan prediksi:

Tabel 8. Hasil Uji Ketepatan Prediksi

\begin{tabular}{|c|c|c|c|c|c|}
\hline \multicolumn{6}{|c|}{ Classification Table ${ }^{a}$} \\
\hline & \multirow{3}{*}{ Observed } & & \multicolumn{3}{|c|}{ Predicted } \\
\hline & & & \multicolumn{2}{|c|}{ Timeliness } & \multirow{2}{*}{$\begin{array}{c}\text { Percentage } \\
\text { Correct }\end{array}$} \\
\hline & & & 0 & 1 & \\
\hline \multirow[t]{3}{*}{ Step 1} & Timeliness & & 31 & 23 & 57,4 \\
\hline & & & 24 & 27 & 52,9 \\
\hline & Overall Per & & & & 55,2 \\
\hline
\end{tabular}

Sumber: Data sekunder yang diolah dalam SPSS 24 (2018)

Berdasarkan pada tabel 8 diatas, hasil menunjukkan bahwa pada kolom, prediksi bagi entitas yang melakukan pelaporan keuangan secara tepat waktunya sebesar 52,9\%. Hal ini berarti dari jumlah perusahaan dalam melakukan penyampaian laporan keuangan sehingga ada berjumlah 27 entitas yang diprediksi akan menyampaikan informasi keuangan tahunan secara tepat waktu dari 51 entitas. Entitas yang melakukan pelaporan keuangan tidak tepat waktunya memiliki kekuatan prediksi sebesar 57,4\%. Hal ini berarti dari total 54 Entitas yang melakukan pelaporan keuangan tahunan tidak tepat waktunya. Model ini memprediksi ada 31 entitas yang tidak melakukan penyampaian informasi keuangan tahunan tepat pada waktu.

\section{Uji Koefisien Regresi}

Uji t dalam regresi logistik dalam menilai signifikansi konstanta. Untuk tiap variabel independen dimana dapat dilihat dalam tabel Variable in the Equation. Pengambilan keputusan berdasarkan nilai apabila hasil probabilitas $>0,05$, maka menerima $\mathrm{H}_{0}$. Kemudian sebaliknya apabila hasil probabilitas $<0,05$, maka menolak $\mathrm{H}_{0}$ (Santoso, 2017:213). Tabel 9 dapat melihat hasil uji koefisien: 
Tabel 9. Hasil Uji Koefisien Regresi Variables in the Equation

\begin{tabular}{|c|c|c|c|c|}
\hline & & B & S.E. & Sig. \\
\hline \multirow[t]{5}{*}{ Step $1^{\mathrm{a}}$} & ROA & ,015 & ,018 & ,390 \\
\hline & CR &,- 154 & ,155 & ,319 \\
\hline & DAR & $-1,513$ & 1,691 & 371 \\
\hline & SIZE &, 031 & ,135 & ,817 \\
\hline & Constant &,- 148 & 4,127 & ,971 \\
\hline
\end{tabular}

Sumber: Data sekunder yang diolah dalam SPSS 24 (2018)

Pada tabel 9 diatas, Nilai signifikansi pada variabel profitabilitas (ROA) sebesar 0,390. Variabel likuiditas (CR) sebesar 0,319. variabel solvabilitas (DAR) sebesar 0,371. Variabel ukuran perusahaan (SIZE) sebesar 0,817. Hal ini menunjukkan bahwa seluruh variabel independen lebih besar daripada 0,05, maka dapat dinyatakan bahwa variabel bebas dalam penelitian ini tidak mempunyai pengaruh signifikan terhadap variabel terikat dalam penelitian ini adalah ketepatan waktu penyampaian laporan keuangan, maka untuk $\mathrm{H}_{1}, \mathrm{H}_{2}, \mathrm{H}_{3}$, dan $\mathrm{H}_{4}$ ditolak.

\section{Omnibus Tests of Model Coefficients}

Omnibus tests of model coefficients merupakan uji yang dimanfaatkan untuk pengujian secara simultan atau serentak. Uji simultan dilaksanakan tujuan untuk menguji apakah pengaruh semua variabel bebas yang diteliti terhadap satu variabel terikat sebagaimana yang telah diformulasikan didalam sebuah model sudah tepat atau tidak (Chandrarin, 2017: 140). Untuk mengambil keputusan nilai apabila probabilitas > 0,05 maka menerima $\mathrm{H}_{0}$. Jika probabilitas < 0,05 maka menolak $\mathrm{H}_{0}$. Tabel 10 dapat melihat hasil omnibus test of model coefficients:

Tabel 10. Hasil Omnibus Tests of Model Coefficients

\begin{tabular}{|c|c|c|c|c|}
\hline \multicolumn{5}{|c|}{ Omnibus Tests of Model Coefficients } \\
\hline & & Chi-square & $d f$ & Sig. \\
\hline \multirow[t]{3}{*}{ Step 1} & Step & 2,599 & 4 & ,627 \\
\hline & Block & 2,599 & 4 & ,627 \\
\hline & Model & 2,599 & 4 & 627 \\
\hline
\end{tabular}

Sumber: Data sekunder yang diolah dalam SPSS 24 (2018)

Berdasarkan tabel 10 diatas dapat dilihat hasil omnibus tests of model coefficient. Tabel menggambarkan bahwa secara simultan profitabilitas (ROA), likuiditas (CR), solvabilitas (DAR) dan ukuran perusahaan secara simultan tidak berpengaruh signifikan terhadap ketepatan waktu penyampaian laporan keuangan. Hal ini ditunjukkan dari tabel bahwa hasil signifikansi dengan nilai 0,627. Nilai signifikansi dimana ditunjukkan tersebut lebih tinggi daripada 0,05. Sehingga dengan demikian maka hipotesis nol diterima.

\section{Profitabilitas Terhadap Ketepatan Waktu Penyampaian Laporan Keuangan}

Variabel profitabilitas (ROA) membuktikan hasil koefisien regresi positif bernilai 0,015 dengan tingkat signifikansi 0,390. Nilai signifikansi tersebut lebih besar dari 0,05 sehingga ketepatan waktu penyampaian laporan keuangan tidak dipengaruhi secara signifikan oleh profitabilitas (ROA). Profitabilitas bukan merupakan suatu tolak ukur utama yang mempengaruhi ketepatan waktu penyampaian laporan keuangan. Perusahaan dengan tingkat profitabilitas yang tinggi maupun yang rendah sama-sama ingin menyampaikan laporan keuangan secara tepat waktu tanpa memperhatikan profitabilitasnya. Suatu perusahaan yang mendapatkan keuntungan yang tinggi belum tentu dapat menggambarkan prestasi manajemen bagus maka yang bisa melakukan penyajian informasi keuangan tepat pada waktunya adalah entitas yang mendapatkan keuntungan tidak dapat dipastikan. Hasil riset tersebut sejalan dengan 
riset sebelumnya yang diteliti oleh Utami \& Yennisa (2017) membuktikan bahwa ketepatan waktu penyampaian laporan keuangan tidak dipengaruhi oleh profitabilitas secara signifikan.

\section{Likuiditas Terhadap Ketepatan Waktu Penyampaian Laporan Keuangan}

Variabel likuiditas (CR) membuktikan bahwa hasil koefisien regresi negatif dengan nilai -0,154 dimana dengan tingkat signifikansi 0,319 . Nilai signifikansi tersebut lebih tinggi daripada 0,05 sehingga ketepatan waktu penyampaian laporan keuangan tidak dipengaruhi secara signifikan oleh likuiditas (CR). likuiditas bukan salah satu fokus kabar baik bagi pengguna laporan keuangan. Kewajiban jangka pendek yang cukup tinggi dalam suatu perusahaan, yang kemudian tidak dapat melakukan pembayaran pada saat jatuh tempo, sehingga bisa saja menyebabkan kewajiban jangka pendek yang dimiliki berubah menjadi jangka panjang. Hasil penelitian sejalan dengan penelitian sebelumnya yang dilakukan oleh Dewayani, Amin, \& Dewi (2017) yang menunjukkan likuiditas tidak mempunyai pengaruh signifikan terhadap ketepatan waktu penyampaian laporan keuangan.

\section{Solvabilitas Terhadap Ketepatan Waktu Penyampaian Laporan Keuangan}

Variabel solvabilitas (DAR) menunjukkan nilai koefisien regresi negatif sebesar -1,513 dengan tingkat signifikansi 0,371 . Nilai signifikansi tersebut lebih besar dari 0,05 sehingga ketepatan waktu penyampaian laporan keuangan tidak dipengaruhi secara signifikan oleh solvabilitas (DAR). Perusahaan dalam menjalankan kegiatan bisnisnya tentu saja memerlukan pinjaman dari pihak luar, utang yang meningkat mendatangkan peluang bagi perusahaan dalam memiliki modal yang besar. Modal yang besar ini akan sangat mendukung perusahaan dalam memperoleh keuntungan. Sehingga, walaupun perusahaan memiliki utang, tetapi perusahaan masih mampu melakukan pembayaran utangnya, maka dari itu informasi mengenai utang ini tidak terlalu diprioritaskan. Hasil riset sama dengan penelitian sebelumnya yang diteliti oleh Mutiara, Zakaria, \& Anggraini (2018) yang menunjukkan bahwa ketepatan waktu penyampaian laporan keuangan tidak dipengaruhi secara signifikan oleh variabel solvabilitas.

\section{Ukuran Perusahaan Terhadap Ketepatan Waktu Penyampaian Laporan Keuangan}

Variabel ukuran perusahaan (SIZE) membuktikan bahwa hasil koefisien regresi positif sebesar 0,031 yang tingkat signifikansi 0,817. Nilai signifikansi tersebut adalah lebih besar daripada 0,05 maka ketepatan waktu penyampaian laporan keuangan tidak dipengaruhi secara signifikan oleh ukuran perusahaan (SIZE). Semakin besarnya suatu informasi yang terkandung didalam suatu perusahaan dapat ditunjukkan oleh ukuran suatu perusahaan, dan juga mencerminkan bahwa pentingnya sebuah informasi bagi pihak manajemen, baik pihak internal maupun pihak eksternal sebuah entitas. Entitas yang mempunyai ukuran besar maupun yang kecil mempunyai kewajiban yang sama untuk memberikan informasi mengenai perusahaannya kepada publik secara tepat waktu. Sebuah informasi yang disampaikan secara tepat waktu akan mendapatkan kepercayaan dari publik mengenai laporan keuangan tersebut. Hasil penelitian ini sejalan dengan penelitian sebelumnya yang dilakukan oleh Imaniar (2016) yang membuktikan bahwa ketepatan waktu penyampaian laporan keuangan tidak dipengaruhi secara signifikan oleh variabel ukuran perusahaan.

\section{Profitabilitas, Likuiditas, Solvabilitas dan Ukuran Perusahaan Terhadap Ketepatan Waktu Penyampaian Laporan Keuangan}

Variabel profitabilitas (ROA), likuiditas (CR), solvabilitas (DAR) dan ukuran perusahaan (SIZE) secara simultan terhadap ketepatan waktu penyampaian laporan keuangan menunjukkan nilai signikansi 0,627 , yang artinya hasilnya besar daripada 0,05 yang menunjukkan bahwa variabel profitabilitas (ROA), likuiditas (CR), solvabilitas (DAR) dan ukuran perusahaan (SIZE) secara simultan tidak berpengaruh signifikan terhadap ketepatan waktu penyampaian laporan keuangan. 


\section{SIMPULAN}

Berdasarkan pada hasil dan pembahasan yang telah diuraikan diatas, maka peneliti menarik kesimpulan sebagai berikut:

1. Profitabilitas (ROA) tidak berpengaruh signifikan terhadap ketepatan waktu penyampaian laporan keuangan. Hal ini dapat dibuktikan bahwa nilai signifikansi sebesar 0,390 yang berarti $0,390>0.05$.

2. Likuiditas (CR) tidak berpengaruh signifikan terhadap ketepatan waktu penyampaian laporan keuangan. Hal ini dapat dibuktikan bahwa nilai signifikansi sebesar 0,319 yang berarti 0,319 $>0,05$.

3. Solvabilitas (DAR) tidak berpengaruh signifikan terhadap ketepatan waktu penyampaian laporan keuangan. Hal ini dapat dibuktikan bahwa nilai signfikansi sebesar 0,371 yang berarti $0,317>0,05$.

4. Ukuran perusahaan (SIZE) tidak berpengaruh signifikan terhadap ketepatan waktu penyampaian laporan keuangan. Hal ini dapat dibuktikan bahwa nilai signfikansi sebesar 0,817 yang berarti $0,817>0,05$.

5. Profitabilitas (ROA), likuiditas (CR), solvabilitas (DAR) dan ukuran perusahaan (SIZE) tidak berpengaruh signifikan secara simultan terhadap ketepatan waktu penyampaian laporan keuangan. Hal ini dapat dibuktikan bahwa nilai signifikansi sebesar 0,627 yang berarti 0,627 $>0,05$.

\section{DAFTAR PUSTAKA}

Chandrarin, G. (2017). Metode Riset Akuntansi Pendekatan Kuantitatif. (A. Suslia, Ed.). Jakarta Selatan: Salemba Empat.

Choiruddin. (2015). Analisis Faktor-Faktor yang Mempengaruhi Ketepatan Waktu Pelaporan Keuangan (Studi Empiris Pada Perusahaan Manufaktur yang Terdaftar di Bursa Efek Indonesia Periode 2009-2013). Jurnal Akuntansi Politeknik Sekayu, Vol.2 No.1, 41-56.

Dewayani, M. A., Amin, M. Al, \& Dewi, V. S. (2017). Analisis Faktor-Faktor yang Memengaruhi Ketepatan Waktu Pelaporan Keuangan (Studi Empiris pada Perusahaan Manufaktur yang Terdaftar di Bursa Efek Indonesia Periode 2011-2016). The 6th University Research Colloquium 2017.

Fahmi, I. (2015). Analisis Laporan Keuangan. Bandung: Alfabeta.

Ghozali, I. (2016). Aplikasi Analisis Multivariate dengan Program IBM SPSS 23. Semarang: Badan Penerbit Universitas Diponegoro.

Hanafi, M. M., \& Halim, A. (2016). Analisis Laporan Keuangan. Yogyakarta: Penerbit: UPP STIM YKPN.

Hery. (2016a). Financial Ratio For Business. Jakarta: PT Grasindo.

Hery. (2016b). Mengenal dan Memahami Dasar-Dasar Laporan Keuangan. Jakarta: Penerbit: PT Grasindo.

Hery. (2017). Kajian Riset Akuntansi. Jakarta: Penerbit: PT Grasindo.

Imaniar, F. Q. (2016). Faktor-Faktor yang Mempengaruhi Ketepatan Waktu Pelaporan Keuangan Perusahaan. Jurnal Ilmu Dan Riset Akuntansi, Vol.5 No.6.

Keputusan Ketua Badan Pengawas Pasar Modal dan Lembaga Keuangan. Penyampaian Laporan Tahunan Emitmen Atau Perusahaan Publik (2012).

Lathiefatunnisa Nur Islam, F. (2015). Faktor-Faktor yang Mempengaruhi Ketepatan Waktu Pelaporan Keuangan Perusahaan: Profitabilitas Sebagai Variabel Moderating (Studi Empiris Pada Perusahaan Manufaktur yang Terdaftar di BEI Tahun 2012 - 2013). Diponegoro Journal Of Accounting, Vol.4 No.4, 1-10.

Mutiara, Y. T., Zakaria, A., \& Anggraini, R. (2018). The Influence of Company Size, Company Profit, Solvency and CPA Firm Size on Audit Report Lag. Journal of Economics, Finance and Accounting, Vol.5(Issue 1), 1-10.

Nurmiati. (2016). Faktor-Faktor yang Mempengaruhi Ketepatan Waktu Pelaporan Keuangan. 
Jurnal Ekonomi Dan Manajemen, Vol.13,(2).

Samryn. (2012). Pengantar Akuntansi: Mudah Membuat Jurnal dengan Pendekatan Siklus Transaksi. Jakarta: PT RajaGrafindo Persada.

Santoso, S. (2012). Aplikasi SPSS Pada Statistik Multivariat. Jakarta: PT Elex Media Komputindo.

Santoso, S. (2017). Menguasai Statistik dengan SPSS 24. Jakarta: PT Elex Media Komputindo. Sudana, I. M. (2011). Manajemen Keuangan Perusahaan Teori dan Praktik. Surabaya: Penerbit: Erlangga.

Utami, D., \& Yennisa. (2017). Faktor-Faktor yang Mempengaruhi Ketepatan Waktu Pelaporan Keuangan Pada Perusahaan Sub Sektor Bank di Bursa Efek Indonesia. Akuntansi Dewantara, Vol.1 No.1 